\title{
Effect of Industries on Soils of Adjoining Areas
}

\author{
Pankaj Kumar* and Rohtas Kumar \\ Department of Soil Science \\ CCS Haryana Agricultural University, Hisar-125004, India
}

*Corresponding author

\section{A B S T R A C T}

\begin{tabular}{|l|}
\hline Ke y w o r d s \\
Industry, \\
Agriculture, \\
Sulphur, Nitrogen, \\
Nutrient
\end{tabular}

The study was conducted to evaluate soil quality and impact of industries on different properties of soils of agricultural field, located in the vicinity of industries and those away from industries at district Rohtak, Haryana. The study was carried out by determining some properties of soil and its nutrient status. The sites selected for sampling were five near the industry and other five away from industries. $\mathrm{pH}$ of soil near industries were found 7.9 to 8.4 and of soil that is away from industries were found 7.53 to 8.00 and organic carbon content in soils near industry and away from industries varies from 0.49 to $0.62 \%$ and 0.02 to $0.39 \%$ respectively. Nutrient content, that is, nitrogen, phosphorus, potassium and sulphur content, in the soils near industry were found higher than the soils that are away from industries. The findings revealed that nutrient $(\mathrm{N}, \mathrm{P}, \mathrm{K})$ content were found higher in soil near industries. The finding of soil properties and nutrient status revealed that the soils away from industries were more near to neutrality and the soil near industries were almost alkali. The nutrient status of soil near industries is higher than that is away from them.

\section{Introduction}

Development of modern technologies has been a key determinant to accelerate industrialization and urbanization in developing countries like India. But in a quest of rapid economic growth, developments are considered key priorities, while protection of environment has not been given the same importance. Thus, a number of factories, sited haphazardly, have been established leading to deterioration of natural resources like soil, water, and air. As a result, environment pollution is tremendously increasing due to industrialization and mechanization that is serving to fulfill demands of population. With increasing population, demand for industrial products for daily use is also increasing establishment of industries is at boom. The net result of industries is called land degradation. Land degradation is reduction of land quality. Productivity of soil declines when land becomes degraded. It declines unless steps are taken to restore that productivity and check further losses. Also data analyses on the agriculture fields near industry from different study reveal that considerable amount of productive and potential agricultural lands has been given to industries. 
With increased industrialization in residential areas, different materials are discharged into effluent water which leads to environment pollution. This concern is of special importance where untreated effluent is applied for longer periods to grow vegetables in urban lands (Yadav et al., 2002, Bharagava et al., 2008). Such uses are on the increase because the effluent contaminated waste water is a free and good source of organic matter as well as plant food nutrient, variable and cheap option for disposal. As a consequence, the use of waste water and other industrial effluents for irrigating agricultural lands is on the rise particularly in peri-urban areas of developing countries (Rajesh et al., 2009; Sing et al., 2010; Arienzo et al., 2009). Long term sustenance of soil fertility of effluent irrigated soils is attributed to the presence of $\mathrm{N}, \mathrm{P}$ and $\mathrm{K}$ in significant quantities in these effluents. Raw sewage and sludge depending upon their source may contain an appreciable amount of metallic micronutrients and heavy toxic metals. Long- term application of these materials to land may cause accumulation of heavy metals in soil and may become toxic to plants (Adhikari et al., 1993). In most of the cities disposal of effluent is carried out by using it for irrigation. This kind of land application of the industrial effluent results in direct addition of trace metals to the soils, resulting in its degradation and also adding of toxic metals in the food chain (Lark et al., 2002).

\section{Materials and Methods}

The soil samples $(0-15 \mathrm{~cm})$ were collected from the fields near the industries and also from the fields those are far away from industries. Numbers of soil samples collected were five from the field that is near to industries and another five from the field that are far away from industries. Before analysis samples were air dried and grinding was done with pestle mortar and pass through $2 \mathrm{~mm}$ sieve.
pH

Twenty gram of soil sample was taken in a $100 \mathrm{ml}$ beaker and $40 \mathrm{ml}$ of distilled water was added to it to make a soil: water suspension of 1:2. The suspension was stirred with glass rod intermittently for 30 minutes and then $\mathrm{pH}$ was measured using $\mathrm{pH}$ meter.

\section{Electrical conductivity (EC)}

Twenty gram of soil sample was taken in a $100 \mathrm{ml}$ beaker and $40 \mathrm{ml}$ of distilled water was added to it to make a soil: water suspension of $1: 2$. The suspension was stirred with glass rod and left for some times so as to settle the soil particles and then EC was measured using conductivity meter.

\section{Calcium carbonate $\left(\mathrm{CaCO}_{3}\right)$}

Calcium carbonate was determined by titrating soil suspension with $0.5 \mathrm{~N}_{2} \mathrm{H}_{2} \mathrm{SO}_{4}$ in the presence of bromothymol blue and bromocresol green indicators. Calcium sulphate and aluminium chloride were also added to make the appearance of colour very distinct. Aluminium chloride was added in order to lower the $\mathrm{pH}$ of the soil suspension, and bring the colour change just at the point, where no carbonates are present. Without its use, even a soil free from $\mathrm{CaCO}_{3}$ gives green colour. Hence, aluminium chloride makes sharp distinction between the soils with or without carbonates (Puri's method)

\section{Organic carbon (OC)}

The organic carbon content of soils was estimated by Wet digestion method (Walkley and Black, 1934). One gram soil was taken in $500 \mathrm{ml}$ conical flask and adds $10 \mathrm{ml}$ potassium dichromate and $20 \mathrm{ml}$ of conc. $\mathrm{H}_{2} \mathrm{SO}_{4}$ to it. Organic matter in the soil was oxidized with a mixture of potassium dichromate and concentrated sulphuric acid, utilizing the heat 
of dilution of sulphuric acid. The excess of potassium dichromate, not reduced by the organic matter of the soil, was determined by titration using $\mathrm{N} / 2$ ferrous ammonium sulphate solution in the presence of sodium fluoride or phosphoric acid using diphenylamine as indicator.

\section{Available nitrogen}

Available nitrogen was determined by alkaline permanganate method (Subbiah and Asija, 1956). Two gram soil was mixed with $20 \mathrm{ml}$ alkaline $\mathrm{KMnO}_{4}$ solution and distilled. The organic matter present in the soil was oxidized by the nascent oxygen, liberated by $\mathrm{KMnO}_{4}$, in the presence of $\mathrm{NaOH}$ and the released ammonia was condensed and absorbed in a known volume of a standard acid, the excess of which was titrated with a standard alkali, using methyl red as an indicator.

\section{Available phosphorus}

Available phosphorus was determined by Olsen's method (Olsen et al., 1954). One gram soil was extracted with $10 \mathrm{ml} 0.5 \mathrm{M} \mathrm{NaHCO}_{3}$ at pH 8.5 in the presence of Darco G-60 (which adsorbs dispersed organic matter and helps in giving clear extract). Phosphorus in the extract was treated with ammonium molybdate, which results in the formation of heteropoly complexes (phosphomolybdate). The phosphomolybdate was reduced by using of $\mathrm{Sncl}_{2}$ (a reducing agent). Due to this reduction, some of $\mathrm{MO}^{6+}$ was converted to $\mathrm{Mo}^{3+}$ or $\mathrm{Mo}^{5+}$, and the complex assumes the blue colour. The intensity of blue colour obtained was measured at wavelength of $660 \mathrm{~nm}$ using red filter on spectrophotometer.

\section{Available potassium}

Available Potassium was determined by Hanway and Heidal (1952). Available Potassium was determined by neutral normal
$\mathrm{NH}_{4} \mathrm{OAC}$ solution using flame photometer. Five gram soil was taken and mixed with $25 \mathrm{ml}$ ammonium acetate. In soil solution $\mathrm{NH}_{4}$ replaces the potassium present in the soil by occupying its sites. At equilibrium there was no replacement of ions and the potassium so obtained in the solution was estimated with a flame photometer.

\section{Available sulphur}

Available Sulphur was determined by using turbidity method (Chesnin and Yien, 1950). Five gram of soil was taken in a conical flask and extract with solution of calcium chloride. Soluble sulphate is estimated in an aliquat of extract, using barium chloride in presence of gum acasia solution. The turbidity produced by barium chloride is measured at $420 \mathrm{~nm}$.

\section{Results and Discussion}

\section{Properties of soils in the adjoining areas and at distance from industries}

The data analyzed for the chemical properties (Table 1 and 2) revealed that $\mathrm{pH}$ of samples collected away from industries ranged between 7.53 to 8.00 and 7.90 to 8.40 for the soils near industries. It indicates that the soils were neutral to alkaline in nature. Electrical conductivity values of the soil samples were recorded higher for soil near industries it varies from 1.30 to $2.90 \mathrm{dSm}^{-1}$ and for soils away from industries it varies between 0.45 to $1.91 \mathrm{dSm}^{-1}$. The EC and $\mathrm{pH}$ of samples from industries vicinity were found higher than that is away from industries. This may be due to build up in salt concentration in soil as a result of wastewater (industrial effluents) application.

The content of organic carbon was recorded higher in the soil samples collected from industries vicinity as compared to that is away from industries. This may be due to the 
application of industrial effluents in the soil nearby the industries which increases the organic matter of the soil. Similar results were obtained by Sahare et al., (2014) they found that soil receiving industrial effluents have higher $\mathrm{pH}, \mathrm{EC}$ and $\mathrm{OC}$ than the soil at distance from industries or not receiving industrial effluents. The variation in calcium carbonate content of the these three land use soils may be due to variation in content of $\mathrm{Ca}^{2+}$ and $\mathrm{CO}_{3}{ }^{2-}$ in irrigation water that was applied to these different land and may also be due to some pedogenic reason processes involved.

Table.1 Properties of soil away from industries

\begin{tabular}{|l|c|c|c|c|}
\hline & $\mathrm{pH}$ & $\mathrm{EC}$ & $\mathrm{OC}$ & $\mathrm{CaCO}_{3}$ \\
\hline Site A & 7.60 & 1.91 & 0.02 & 2.10 \\
\hline Site B & 7.63 & 2.18 & 0.29 & 2.00 \\
\hline Site C & 8.00 & 0.45 & 0.39 & 5.00 \\
\hline Site D & 7.60 & 0.52 & 0.23 & 0.00 \\
\hline Site E & 7.53 & 1.08 & 0.35 & 0.00 \\
\hline
\end{tabular}

Table.2 Properties of soil near industries

\begin{tabular}{|l|c|c|c|c|}
\hline & $\mathrm{pH}$ & $\mathrm{EC}$ & $\mathrm{OC}$ & $\mathrm{CaCO}_{3}$ \\
\hline Site 1 & 8.40 & 2.90 & 0.51 & 2.10 \\
\hline Site 2 & 7.90 & 1.64 & 0.52 & 2.00 \\
\hline Site 3 & 8.00 & 1.30 & 0.62 & 0.00 \\
\hline Site 4 & 8.00 & 1.86 & 0.53 & 0.00 \\
\hline Site 5 & 8.20 & 2.10 & 0.49 & 3.50 \\
\hline
\end{tabular}

Table.3 Properties of soil away from industries

\begin{tabular}{|l|c|c|c|c|}
\hline & $\mathrm{N}$ & $\mathrm{P}$ & $\mathrm{K}$ & $\mathrm{S}$ \\
\hline Site A & 80.00 & 11.00 & 248.00 & 68.40 \\
\hline Site B & 133.00 & 14.00 & 232.00 & 63.00 \\
\hline Site C & 126.00 & 13.00 & 245.33 & 39.12 \\
\hline Site D & 119.00 & 12.00 & 248.00 & 63.90 \\
\hline Site E & 133.00 & 14.00 & 192.00 & 62.40 \\
\hline
\end{tabular}

Table.4 Properties of soil near industries

\begin{tabular}{|l|c|c|c|c|}
\hline & N & P & K & S \\
\hline Site 1 & 266.00 & 15.00 & 337.84 & 90.40 \\
\hline Site 2 & 228.00 & 15.00 & 351.17 & 90.54 \\
\hline Site 3 & 210.00 & 16.00 & 324.51 & 67.88 \\
\hline Site 4 & 280.00 & 18.00 & 340.51 & 85.22 \\
\hline Site 5 & 213.00 & 15.00 & 339.17 & 90.54 \\
\hline
\end{tabular}


Fig.1 Comparison of nutrient status of soils in the adjoining areas and at distance from industries

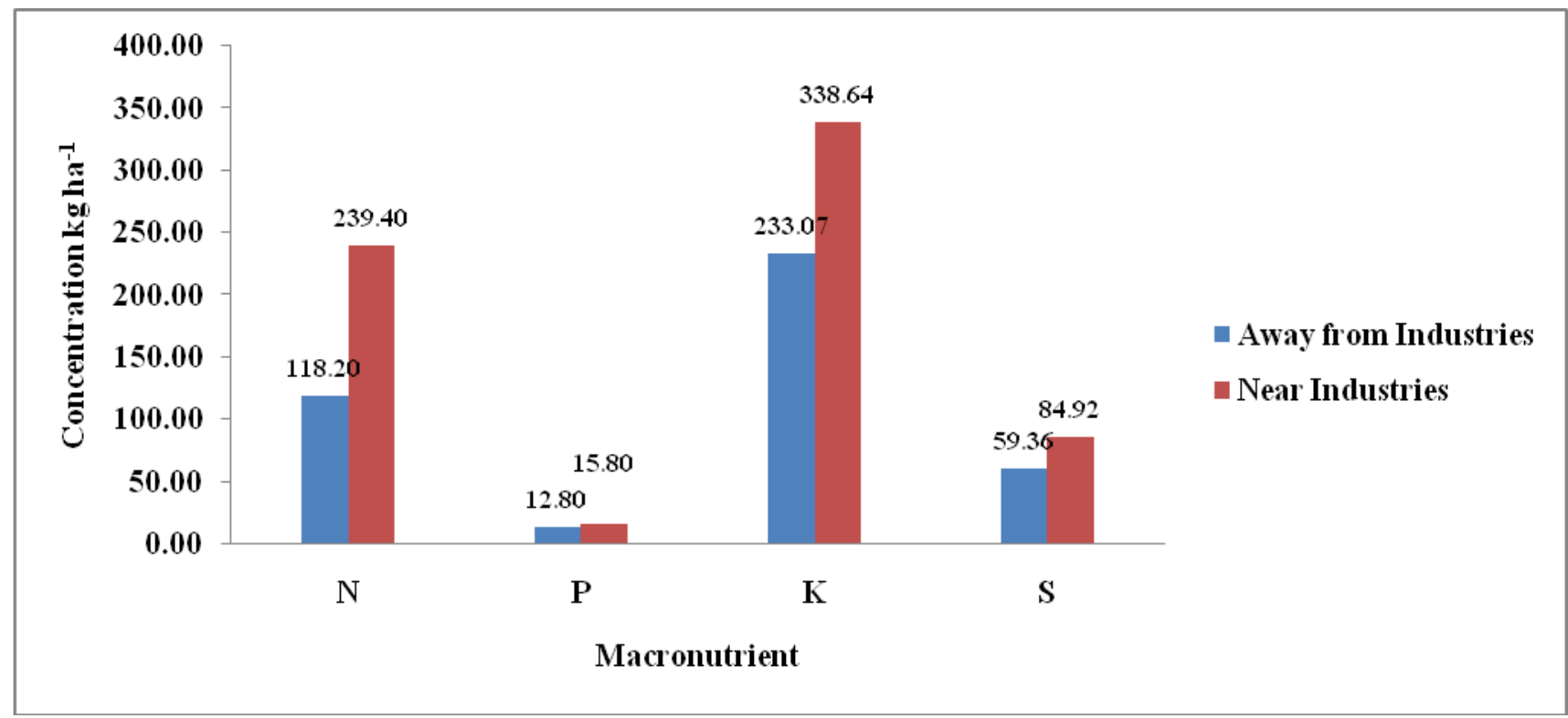

Nutrient status of soils in the adjoining areas and at distance from industries

The analysis of samples for available macronutrients $\mathrm{N}, \mathrm{P}, \mathrm{K}$ and $\mathrm{S}$ status of soils near and away from industries is given in Table 4 and 3 respectively it revealed that the higher concentration $\mathrm{N}, \mathrm{P}, \mathrm{K}$ and $\mathrm{S}$ were found is soils near industries than those of that is away from industries. Higher content of $\mathrm{N}, \mathrm{P}, \mathrm{K}$ and $\mathrm{S}$ in soils near industries may be due to accumulation of these nutrients in soil as a result of wastewater application to soil. Many investigators reported that soil fertility increased as a consequence of the application of wastewater, sewage sludge, etc. (Chakrabarti, 1995; Manicas et al., 1998).

Increase in $\mathrm{N}, \mathrm{P}, \mathrm{K}$ and $\mathrm{S}$ can also be due to increase in organic matter under industrial land use. This is probably due to high organic matter supplied with the wastewater. Other researchers found that application of wastewater irrigation resulted in about 4, 10 and 8 fold increases in $\mathrm{N}, \mathrm{P}, \mathrm{K}$, respectively, above the recommended fertilizer rates for forage crops (Burns et al., 1985). Similar results were obtained by Rajput et al., (2017) they found that the industrial effluentirrigated soils have higher total $\mathrm{N}, \mathrm{P}, \mathrm{K}$ and $\mathrm{S}$ indicating their significant addition through industrial effluent. The higher availability of $S$ under industrial land use soil may be due to high $\mathrm{pH}$ as the availability of sulphur increases with increase in $\mathrm{pH}$ or due to presence of sulphur in industrial effluents.

Comparison of nutrient status of soils in the adjoining areas and at distance from industries

The mean content of $\mathrm{N}, \mathrm{P}, \mathrm{K}$ and $\mathrm{S}$ of soil away from industries and that is near to industries is presented in figure 1. It was found that higher content of these nutrients were found in soils that is in vicinity of the industries than those that is away from industries. This may be due to application of industrial effluents or due to presence of higher organic matter under industrial land use (Rajput et al., (2017). 


\section{References}

Adhikari, S., Gupta, S.K. and Banerjee, S.K. J. 1993. Indian Society of Soil Scence. 41:160-172.

Arienzo, V., Christen, E.W., Quayle, W. and Kumar, A. 2009. Journal of Hazardous Materials, 164(2/3): 415-422.

Bharagava, R.N., Chandra, R. and Rai, V. 2008. Bioresource Technology, 99, 17, 8316-8324.

Burns, J.C., Westerman, P.W., King, L.D., Cummings, G.A., Overcash, M.R., Goode, L.1985. Swine lagoon effluent applied to Coastal Bermudagrass. Forage yield, quality and element removal. Journal of Enviromental Quality, 14: 9-14.

Chakrabarti, C. 1995. Residual effects of long-term land application of domestic wastewater.

Environment International,21:333-339.

Chesnin, L. and Yien, C.H. 1950. Turbidimetric determination of available sulphates. Proceedings of Soil Science Society of America, 14: 149-151.

Hanway, J. J. and Heidel, H. 1952. Soil analysis methods as used in Iowa State College, Soil Testing Laboratory. Iowa State College Bull,57: 1-131.

Lark B.S., Mahajan R.K. and Walia T.P.S. 2002. Indian Journal of Environment Health, 44(2): 164-167

Manicas, P., Navas, A., Bermudez, F., Machn, J. 1998. Influence of sewage sludge application on physical and chemical properties of Gypsisols. Geoderma, 87: 123-135.
Olsen, S.R., Cole, C.V., Watanabe, F.S. and Dean, L.A. 1954. Estimation of available phosphorus in soils by extraction with sodium bicarbonate. Circular U.S. Department of Agriculture939.

Rajesh, D., Sunil, C., Lalita, R. and Sushila, S. 2009. European Journal of Soil Biology, 45(5/6): 459-465.

Rajput, S. G., Tiwari, D.D., Katiyar, N.K, Kumar, A., Pathak, R. K. and Srivastava, V. 2017. Effect of industrial effluent on soil properties, essential nutrient and pollutant element status of soils and plants in a vegetable growing near Jajmau industrial area of Kanpur, Uttar Pradesh, India. Research on Crops, 18(2): 249-255.

Sahare, D., Rajput, S.K. and Dwivedi, P.R. 2014. Impact of irrigation of industrial effluents on soil-plant health. International Journal on Recent and Innovation Trends in Computing and Communication, 2 (12).

Singh, G., Bhati, M. and Rathod, T. 2010. Ecological Engineering, 36(10): 12991306.

Subbiah, B.V. and Asija, G.L. 1956. A rapid procedure for the determination of available nitrogen in soils. Current Science, 25: 259-60.

Walkley, A.J. and Black, C.A. 1934. Estimation of soil organic carbon by the chromic acid titration method. Soil Science,37:29-38.

Yadav, R.K., Goyal, B., Sharma, R.K., Dubey, S.K. and Minhas, P.S. 2002. Environment International, 28(6): 481-486.

\section{How to cite this article:}

Pankaj Kumar and Rohtas Kumar. 2018. Effect of Industries on Soils of Adjoining Areas. Int.J.Curr.Microbiol.App.Sci. 7(07): 126-131. doi: https://doi.org/10.20546/ijcmas.2018.707.015 